Edisi Januari - Juni 2020 Vol 19 No 1

\section{JURNAL ILMU PEMERINTAHAN}

\section{nakhoda}

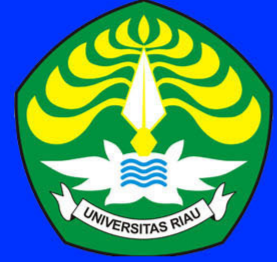

Innovation Hub: Media Kolaborasi Menuju Pemerintahan Daerah Inovatif Herie Saksono

Institusional Building dalam Mengatasi Persoalan Pertambangan Emas Tanpa Izin Di Kabupaten Kuantan Singingi Provinsi Riau

Khotami

Gerakan Masyarakat Tertib Administrasi Kependudukan Melalui Inovasi Pelayanan Lukadesi (Keluarga Berduka Desa Siaga)

Di Kabupaten Sleman D.I Yogyakarta

Hendy Setiawan, Fariza Ikhsanditya

Provinsi 'Istimewa Melayu Riau Kepulauan'

Muchid Albintani, Auradian Marta

Kaderisasi dan Penetapan Calon Legislatif pada Partai Politik (Studi DPD Partai Nasional Demokrat Seram Bagian Barat 2019)

Fandi Ahmad Sintani, Wahab Tuanaya, Marno Wance

Factors of Affect Deliberation of Maguwoharjo

Village Development Planing Sub-District Depok Regency Sleman Yogyakarta Muhammad Rafi, Ulung Pribadi, Fajar Rahmanto

Survey Kepuasan Masyarakat (SKM) pada Badan PendapatanDaerah Kabupaten Bintan

Suherry, Billy Jenawi, Rendra Setyadiharja,

Zamzami A Karim, Firman Setyawan, Rany Angraini

Peran Dewan Perwakilan Daerah (DPD) dalam

Pembentukan Daerah Otonomi Baru (DOB) Di wilayah Provinsi Maluku Utara

Abdul Halil Ibrahim, Bakri La Suhu, Rifjal Tifandy, Marno Wance

MEDIA INFORMASI DAN KOMUNIKASI ILMIAH CIVITAS AKADEMIKA JURUSAN ILMU PEMERINTAHAN

FAKULTAS ILMU SOSIAL DAN ILMU POLITIK

UNIVERSITAS RIAU
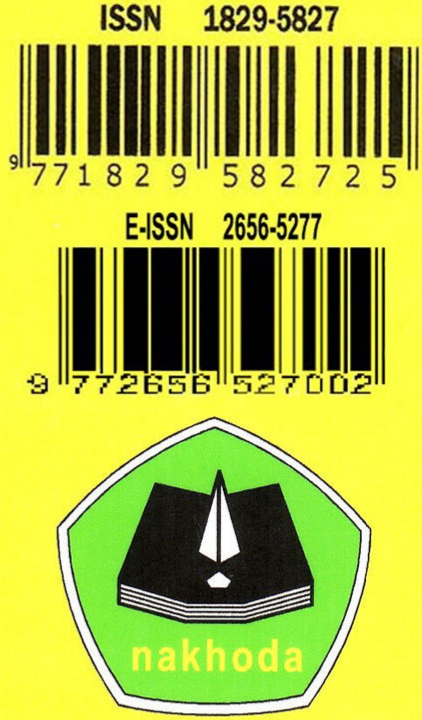

DITERBITKAN OLEH :

LABORATORIUM ILMU PEMERINTAHAN
SEKRETARIAT :

KAMPUS BINA WIDYA SIMPANG BARU

PANAM KM. 12,5 PEKANBARU

(28293) Telp/Fax. (0761)63277 
NAKHODA:

JURNAL

ILMU PEMERINTAHAN
NAKHODA: JURNAL ILMU PEMERINTAHAN

Edisi Januari - Juni 2020 Volume: 19 Nomor: 1

ISSN : 1829-5827 | E-ISSN : 2656-5277

DOI : https://doi.org/10.35967/jipn

https://nakhoda.ejournal.unri.ac.id/index.php/JIPN

INNOVATION HUB: MEDIA KOLABORASI MENUJU PEMERINTAHAN DAERAH INOVATIF

Herie Saksono

Badan Penelitian dan Pengembangan (BPP) Kementerian Dalam Negeri, Jakarta, Indonesia

$1-16$

INSTITUTION BUILDING DALAM MENGATASI PERSOALAN PERTAMBANGAN EMAS

TANPA IZIN DI KABUPATEN KUANTAN SINGINGI PROVINSI RIAU

Khotami

Program Studi Ilmu Pemerintahan, Fakultas IImu Sosial dan IImu Politik Universitas Islam Riau. 17 - 37

Pekanbaru-Indonesia

GERAKAN MASYARAKAT TERTIB ADMINISTRASI KEPENDUDUKAN MELALUI INOVASI

PELAYANAN LUKADESI (KELUARGA BERDUKA DESA SIAGA) DI KABUPATEN SLEMAN

D.I. YOGYAKARTA

Hendy Setiawan ${ }^{1}$, Fariza Ikhsanditya ${ }^{2}$

1,2 Departemen IImu Pemerintahan, Universitas Muhammadiyah Yogyakarta, Yogyakarta,

Indonesia

PROVINSI “ISTIMEWA MELAYU KEPULAUAN RIAU” (GAGASAN PERMULAAN)

Muchid Albintani', Auradian Marta ${ }^{2}$

1,2 Jurusan IImu Pemerintahan, Fakultas IImu Sosial dan IImu Politik, Universitas Riau

KADERISASI DAN PENETAPAN CALON LEGISLATIF PADA PARTAI POLITIK (Studi DPD

Partai Nasional Demokrat Seram Bagian Barat 2019

Fandi Ahmad Sintani ${ }^{1}$, Wahab Tuanaya ${ }^{2}$, Marno Wance ${ }^{3}$

1,2,3 Jurusan IImu Pemerintahan, Universitas Pattimura, Indonesia

$75-90$

FACTORS THAT AFFECT DELIBERATION OF MAGUWOHARJO VILLAGE DEVELOPMENT

PLANNING SUB-DISTRICT DEPOK REGENCY SLEMAN YOGYAKARTA

Muhammad Rafi ${ }^{1}$, Ulung Pribadi2, Fajar Rahmanto ${ }^{3}$

1,2,3 Department of Government Affairs and Administration, Universitas Muhammadiyah

Yogyakarta, Indonesia

SURVEY KEPUASAN MASYARAKAT (SKM) PADA BADAN PENDAPATAN DAERAH

KABUPATEN BINTAN

Suherry ${ }^{1}$, Billy Jenawi², Rendra Setyadihardja ${ }^{3}$, Zamzami A. Karim4,

Firman Setiawan ${ }^{5}$, Rany Angraini ${ }^{6}$

$102-112$

1,2,3,4 STISIPOL Raja Haji, Tanjungpinang, Indonesia

5,6 Bapelitbang, Bintan, Indonesia

PERAN DEWAN PERWAKILAN DAERAH (DPD) DALAM PEMBENTUKAN DAERAH

OTONOMI BARU (DOB) DI WILAYAH PROVINSI MALUKU UTARA

Abdulhalil Hi. Ibrahim ${ }^{1}$, Bakri La Suhu2, Rifjal Tifandy 3 Marno Wance 4

1,2,3 IImu Pemerintahan Universitas Muhammadiyah Maluku Utara, Kota Ternate, Indonesia

$113-127$

${ }^{4}$ IImu Pemerintahan, Universitas Pattimura, Kota Ambon, Indonesia 


\title{
INSTITUTION BUILDING DALAM MENGATASI PERSOALAN PERTAMBANGAN EMAS TANPA IZIN DI KABUPATEN KUANTAN SINGINGI PROVINSI RIAU
}

\author{
Khotami \\ Program Studi Ilmu Pemerintahan, Fakultas Ilmu Sosial dan Ilmu Politik Universitas Islam Riau. Pekanbaru- \\ Indonesia \\ E-mail: khotami.ip@soc.uir.ac.id
}

\begin{abstract}
ABSTRAK
Penelitian ini dilakukan di Kabupaten Kuantan Singingi yang dimotivasi oleh munculnya kegiatan penambangan emas tanpa izin (PETI) di sejumlah kabupaten di Kabupaten Kuantan Singingi yang dilakukan oleh masyarakat setempat. Hal ini disebabkan oleh pendapatan yang menjanjikan sehingga kegiatan tersebut dijadikan mata pencaharian. Penambangan emas tanpa izin di Kabupaten Kuantan Singingi merupakan masalah yang telah menjadi perbincangan di antara masyarakat Riau pada umumnya. Masalah ini harus dipecahkan oleh pihak-pihak yang berkepentingan sehingga dampak dari kegiatan penambangan emas tidak akan membahayakan wilayah atau orang-orang yang tinggal di daerah sekitar lokasi tambang. Faktor kurangnya kesadaran publik tentang bahaya PETI telah menyebabkan pertumbuhan PETI tumbuh, di samping rendahnya tingkat keterlibatan aktor yang tertarik dan partisipasi masyarakat dalam perumusan kebijakan sehingga mempengaruhi produk regulasi yang lemah yang merupakan payung hukum bagi PETI. kegiatan penambangan emas yang merugikan masyarakat setempat. Studi ini melihat bagaimana struktur kelembagaan menangani masalah penambangan emas tanpa izin di Kabupaten Kuantan Singingi. Metode yang digunakan dalam penelitian ini menggunakan pendekatan kualitatif. Informan dalam penelitian ini terdiri dari Pegawai Dinas ESDM Provinsi Riau, DPRD, Asisten III Sekretariat Daerah Kuantan Singingi, Petugas Kepolisian Kabupaten Kuantan Singingi, Pegawai Dinas Lingkungan Kabupaten Kuantan Singingi, Kepala Desa dan masyarakat. Teknik pengumpulan data dilakukan dengan observasi, wawancara dan dokumentasi.

Hasil penelitian menunjukkan bahwa lemahnya peran kepemimpinan baik formal maupun informal dalam mengawasi kegiatan yang dilakukan oleh pemilik modal dan pelaku pertambangan. Selain itu tidak ada aturan dalam bentuk peraturan daerah sebagai payung hukum terkait penambangan masyarakat. Sumber daya yang terbatas dalam bentuk biaya, fasilitas, dan jarak lokasi penambangan membuatnya sulit dikendalikan oleh polisi. Oleh karena itu, diperlukan kerja sama dalam pengembangan kelembagaan antara pemerintah provinsi dan pemerintah kabupaten, DPRD dan masyarakat dalam mengatasi masalah penambangan emas tanpa izin di Kabupaten Kuantan Singingi.
\end{abstract}

\section{Kata Kunci: Institution Building, Pengelolaan, Pertambangan}

\section{PENDAHULUAN}

Amanat dari Undang-Undang Nomor 23 Tahun 2014 tentang Pemerintahan Daerah[1] diarahkan untuk mempercepat terwujudnya kesejahteraan masyarakat melalui peningkatan pelayanan, pemberdayaan dan peran serta masyarakat. Oleh karenanya hubungan dan pengembangan antar kelembagaan (institution building) pemerintah perlu dilaksanakan sebagai implementasi dari pasal-pasal didalam Undang-Undang tersebut guna menyelenggarakan urusan pemerintahan baik antara lembaga 
NAKHODA: JURNAL ILMU PEMERINTAHAN

Edisi Januari - Juni Tahun 2020 Volume: 19 Nomor: 1

ISSN : 1829-5827 | E-ISSN : 2656-5277

DOI : https://doi.org/10.35967/jipn

https://nakhoda.ejournal.unri.ac.id/index.php/JIPN pemerintah dengan pemerintah daerah maupun pemerintah daerah dengan pemerintah daerah lainnya. Hubungan sebagaimana dimaksud meliputi hubungan wewenang, keuangan, pelayanan umum, pemanfaatan sumber daya alam, dan sumber daya lainnya. Sementara hubungan yang dimaksud akan menimbulkan hubungan administrasi dan kewilayahan antar susunan pemerintahan.

Secara konseptual institution building (pembangunan kelembagaan) telah dipopulerkan oleh Milton J. Esman (1972)[2] yang menguraikan kerangka konseptualnya dengan pandangan yang meyakinkan. Esman memfokuskan pandangannya pada penciptaan dan pemulihan terhadap institusi dengan memperkenalkan perubahan teknis dan/atau sosial ke negara-negara berkembang yang mencakup elemen kepemimpinan institusi, doktrin, program, sumber daya, dan struktur internal yang memiliki keterkaitan dengan lingkungan eksternal, fungsional, normatif, dan hubungan yang tersebar. Selain itu, Hudock \& Stewart (1995)[3] menjelaskan tentang bangunan lembaga yang terdiri dari dua bagian, yakni kegiatan yang 'membangun organisasi' yang meningkatkan kinerja organisasi, dan kegiatan lain yang 'dimaksudkan untuk mengubah mekanisme yang melaluinya masyarakat diatur'.

Studi tentang institution building telah dilakukan oleh para sarjana dengan fokus yang berbeda. diantaranya penelitian yang dilakukan oleh Eriksen (2007)[4] membahas bagaimana dan sejauh mana pengaruh eksternal (yaitu, aktor, sumber daya, norma dan model administrasi) telah mempengaruhi reformasi kelembagaan di wilayah yang selama berabad-abad telah didominasi oleh kekuatan asing. Penelitian lain yang terkait dengan institutional building yakni dilakukan oleh Vidhya (2009)[5] yang mengulas tentang pengembangan kelembagaan dari aspek bisnis dan dimensi kepemimpinan, nilai dan budaya. Selanjutnya penelitian yang dilakukan Terada (2001)[6] yang membahas peran kepemimpinan Jepang dalam membangun lembaga-lembaga ekonomi Asia Pasifik, dengan fokus pada hubungannya dengan ASEAN dari perspektif kepemimpinan terarah. Sedangkan dalam penelitian ini membahas tentang institution building dalam mengatasi permasalahan yang terkait dengan pertambangan emas di Kabupaten Kuantan Singingi yang relatif belum dibahas oleh penelitian sebelumnya.

$$
\text { Selanjutnya berkaitan dengan }
$$

konteks penelitian tentang persoalan pertambangan emas tanpa izin di Kabupaten Kuantan Singingi, bahwa pemerintah daerah melaksanakan urusan pemerintahan yang salah satunya yakni penyelenggaraan urusan pemerintahan dibidang pertambangan berdasarkan Undang-Undang Nomor 23 Tahun 2014 tentang Pemerintahan Daerah yakni Pasal 14 ayat (1) dimana urusan pertambangan tersebut dibagi antara pemerintah pusat dengan pemerintah daerah provinsi. Berdasarkan ketentuan Undang-Undang tersebut, kewenangan pertambangan sejatinya berada pada pemerintah provinsi yang mana sebelumnya juga dimiliki oleh pemerintah kabupaten. Sementara itu, dalam rangka melaksanakan urusan pemerintahan, mengacu pada pendapat 
NAKHODA: JURNAL ILMU PEMERINTAHAN

Edisi Januari - Juni Tahun 2020 Volume: 19 Nomor: 1

ISSN : 1829-5827 | E-ISSN : 2656-5277

DOI : https://doi.org/10.35967/jipn

https://nakhoda.ejournal.unri.ac.id/index.php/JIPN
William S. Pooler dan Richard L. Duncan meyatakan bahwa pemerintah sebagai organisasi formal memiliki wewenang dalam menyediakan fungsi dan layanan yang bernilai. Mereka berfungsi sebagai model untuk mendefinisikan pola normatif dan nilai yang sah, melestarikan dan melindungi mereka untuk masyarakat yang lebih besar (Dalam Donald, G., de Schweinitz Jr, K., \& Klein, P. A. 1974)[7]. Berkaitan dengan persoalan pertambangan emas tanpa izin di Kabupaten Kuantan Singingi, sesungguhnya kegiatan tersebut telah terjadi sejak tahun 2002 dengan proses eksplorasi dilakukan dengan menggunakan alat berat dan penggunaaan zat-zat kimiawi yang dapat membahayakan. Kegiatan penambangan emas yang dilakukan tanpa mengantongi izin ini telah mengalami perkembangan sejak tahun 2009 dengan wilayah pertambangan meliputi hampir seluruh kecamatan yang ada di Kabupaten Kuantan Singingi. Maraknya aktivitas penambangan emas tanpa izin pada sejumlah kecamatan di Kabupaten Kuantan Singingi ini sebagian besar dilakukan oleh masyarakat setempat. Faktor yang mempengaruhi maraknya kegiatan penambangan emas tanpa izin ini disebabkan oleh penghasilan yang menjanjikan sehingga masyarakat setempat menjadikan kegiatan penambangan ilegal ini sebagai mata pencaharian. Sementara itu kurangnya kesadaran masyarakat sekitar pinggiran sungai akan bahaya PETI menyebabkan kian maraknya pertumbuhan PETI karena pemilik tanah sekitar pinggiran sungai, aparat desa, juga pemuda setempat mendapatkan fee dari aktifitas penambangan tersebut. Rendahnya tingkat keterlibatan aktor berkepentingan dan partisipasi masyarakat dalam perumusan kebijakan sehingga berpengaruh terhadap lemahnya produk aturan yang menjadi payung hukum kegiatan pertambangan emas di Provinsi Riau yang menjadi salah satu faktor pendorong tumbuh dan berkembangnya kegiatan pertambangan emas ilegal yang merugikan pemerintah dan masyarakat setempat. Akibat dari kegiatan pertambangan ilegal tersebut, menyebabkan rusaknya lahan dan tercemarnya air sungai serta terjadi abrasi secara besar-besaran yang dapat merusak lingkungan dan terganggunya kehidupan biota sungai maupun hilangnya mata pencaharian masyarakat yang berada disekitar aktivitas pertambangan tersebut. Adapun kerusakan lahan yang diakibatkan oleh kegiatan penambangan emas ilegal tersebut dapat dilihat pada grafik dibawah ini: 
NAKHODA: JURNAL ILMU PEMERINTAHAN

Edisi Januari - Juni Tahun 2020 Volume: 19 Nomor: 1

ISSN : 1829-5827 | E-ISSN : 2656-5277

DOI : https://doi.org/10.35967/jipn

https://nakhoda.ejournal.unri.ac.id/index.php/JIPN

\section{Gambar 1.}

\section{Kerusakan lahan Akibat Aktivitas PETI di Kabupaten Kuantan Singingi}

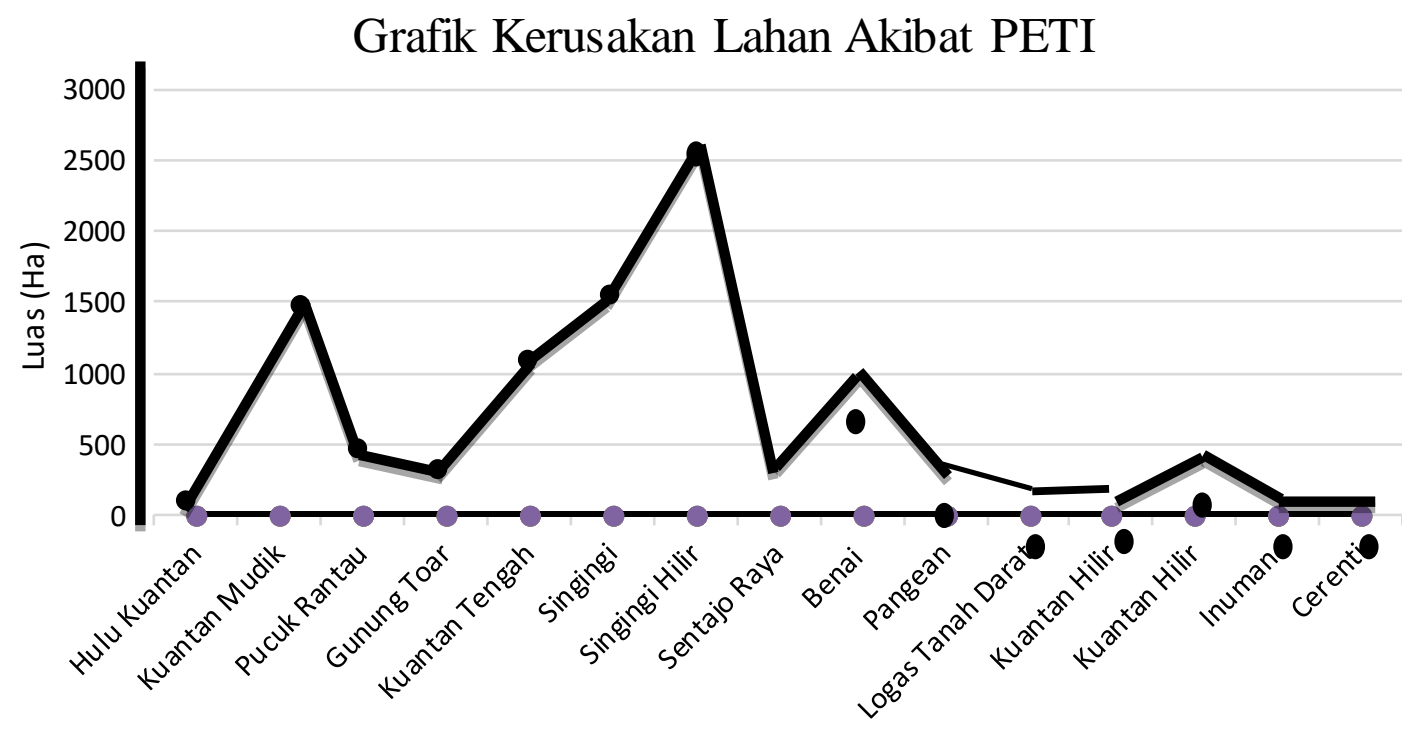

Kecamatan

\section{Sumber: Dinas Lingkungan Hidup Kabupaten Kuantan Singingi, 2020}

Berdasarkan data diatas sangat jelas terlihat kerusakan lahan akibat aktivitas pertambangan emas tanpa izin yang tersebar diseluruh kecamatan di Kabupaten Kuantan Singingi kecuali beberapa kecamatan yang tidak terjadi kerusakan lahan. Hal ini menunjukkan bahwa hampir sebagian besar wilayah di Kabupaten Kuantan Singingi terdapat aktivitas PETI yang menyebabkan terjadinya kerusakan lahan. Akibat dari aktivitas pertambangan yang masih bersifat ilegal ini akan menimbulkan lebih banyak kerugian dan persoalan, baik bagi negara maupun bagi masyarakat, dibandingkan dari manfaat yang dapat diperoleh. Betapa tidak, jika sebagian besar daerah di Indonesia sebagai pengahasil tambang melakukan kegiatan pertambangan secara ilegal maka negara akan kehilangan pendapatan karena para penambang tidak membayar pajak dan royalti, akibatnya terjadi pemborosan sumberdaya. Oleh karenanya berdasarkan hal tersebut, maka pertanyaan dalam penelitian ini yakni: Bagaimana institution building (pembangunan kelembagaan) dalam mengatasi persoalan pertambangan emas tanpa izin di Kabupaten Kuantan Singingi?

\section{KERANGKA TEORI}

Adapun defenisi dari pengembangan kelembagaan sesuai dengan tulisan Milton J. Esman (1972) yakni: "Pembangunan kelembagaan dapat didefinisikan sebagai perencanaan, penataan, dan panduan organisasi baru 
NAKHODA: JURNAL ILMU PEMERINTAHAN

Edisi Januari - Juni Tahun 2020 Volume: 19 Nomor: 1

ISSN : 1829-5827 | E-ISSN : 2656-5277

DOI : https://doi.org/10.35967/jipn

https://nakhoda.ejournal.unri.ac.id/index.php/JIPN atau yang dibentuk ulang yang (a) mewujudkan perubahan nilai, fungsi, fisik, dan / atau teknologi sosial, (b) membangun, membina, dan melindungi normatif baru hubungan dan pola tindakan, dan (c) mendapatkan dukungan dan saling melengkapi di lingkungan". Berbeda dengan William S. Pooler dan Richard L. Duncan dalam (Donald\&Klein, 1974), yang menyarankan bahwa institusi adalah "organisasi formal spesifik yang seiring waktu telah mengembangkan kapasitas untuk bertindak sebagai agen untuk masyarakat yang lebih besar dengan menyediakan fungsi dan layanan yang bernilai mereka berfungsi sebagai model untuk mendefinisikan pola normatif dan nilai yang sah, melestarikan dan melindungi mereka untuk masyarakat yang lebih besar "

Lebih lanjut Milton J. Esman, tampaknya juru bicara institutional building yang terkenal, menjabarkan kerangka kerja konseptualnya dengan tangan yang meyakinkan. Singkatnya, ini mencakup fokus kepentingan tertentu dalam penciptaan dipandu atau pemulihan institusi yang dimaksudkan untuk memperkenalkan perubahan teknis dan/atau sosial ke negara-negara berkembang. Fokus semacam itu mencakup variabel internal ke kepemimpinan institusi, doktrin, program, sumber daya, dan struktur internal dan keterkaitan institusi dengan lingkungan eksternal yang memungkinkan, fungsional, normatif, dan hubungan yang tersebar.

Kelembagaan umumnya banyak dibahas dalam sosiologi, antropologi, hukum dan politik, organisasi dan manajemen, psikologi maupun ilmu lingkungan yang kemudian berkembang ke dalam ilmu ekonomi karena kini mulai banyak ekonom berkesimpulan bahwa kegagalan pembangunan ekonomi umumnya karena kegagalan kelembagaan. Dalam bidang sosiologi dan antropologi kelembagaan banyak ditekankan pada norma, tingkah laku dan adat istiadat. Dalam bidang ilmu politik kelembagaan banyak ditekankan pada aturan main (the rules) dan kegiatan kolektif (collective action) untuk kepentingan bersama atau umum (public). Ilmu psikologi melihat kelembagaan dari sudut tingkah laku manusia (behaviour). Ilmu hukum menegaskan pentingnya kelembagaan dari sudut hukum, aturan dan penegakan hukum serta instrumen dan proses litigasinya (Djogo, dkk, 2003)[8].

$$
\text { Djogo dkk (2003) juga }
$$

menyebutkan bahwa pada umumnya definisi lembaga mencakup konsep pola perilaku sosial yang sudah mengakar dan berlangsung terus menerus atau berulang. Dalam konteks ini sangat penting diperhatikan bahwa perilaku sosial tidak membatasi lembaga pada peraturan yang mengatur perilaku tersebut atau mewajibkan orang atau organisasi untuk harus berpikir positif ke arah norma-norma yang menjelaskan perilaku mereka tetapi juga pemahaman akan lembaga ini memusatkan perhatian pada pengertian mengapa orang berprilaku atau bertindak sesuai dengan atau bertentangan dengan peraturan yang ada. Kelembagaan berisikan dua aspek penting yaitu; "aspek kelembagaan" dan "aspek keorganisasian". Aspek kelembagaan meliputi perilaku atau perilaku sosial dimana inti kajiannya adalah tentang nilai (value), norma (norm), 
NAKHODA: JURNAL ILMU PEMERINTAHAN

Edisi Januari - Juni Tahun 2020 Volume: 19 Nomor: 1

ISSN : 1829-5827 | E-ISSN : 2656-5277

DOI : https://doi.org/10.35967/jipn

https://nakhoda.ejournal.unri.ac.id/index.php/JIPN custom, mores, folkways, usage, kepercayaan, gagasan, doktrin, keinginan, kebutuhan, orientasi dan lain-lain. Bentuk perubahan sosial dalam aspek kelembagaan bersifat kultural dan proses perubahannya membutuhkan waktu yang lama. Sementara dalam aspek keorganisasian meliputi struktur atau struktur sosial dengan inti kajiannya terletak pada aspek peran (role).

Lebih jauh aspek struktural mencakup: peran, aktivitas, hubungan antar peran, integrasi sosial, struktur umum, perbandingan struktur tekstual dengan struktur faktual, struktur kewenangan atau kekuasaan, hubungan antar kegiatan dengan tujuan yang hendak dicapai, aspek solidaritas, klik, profil dan pola kekuasaan. Bentuk perubahan sosial dalam aspek keorganisasian bersifat struktural dan berlangsung relatif cepat (Subagio, 2005)[9].

Pembahasan tentang institution building telah banyak dilakukan oleh para sarjana diberbagai negara dengan melihat dari perspektif yang berbeda-beda. Diantaranya Eriksen (2007) yang melakukan penelitiannya di Eropa melalui hasil penelitiannya menunjukkan: pertama, bagaimana tiga aspek pemerintah dari apa yang disebut tradisi administratif dan budaya negara-negara transisi, kepemimpinan politik dan manajemen reformasi mempengaruhi sejauh mana negara-negara ini ditembus oleh pengaruh luar atau mendapat keuntungan dari bantuan eksternal di bidang administrasi publik.

Kedua,

bagaimana

kebijakan/model kelembagaan dapat ditransfer antar negara dan budaya dengan cara yang berbeda dan bagaimana berbagai modalitas transfer dapat membentuk dampak keterlibatan asing. Selain itu, oleh S.R. Ganesh (1980)[10] yang mencoba untuk mensintesis berbagai aliran yang relevan di bidang usaha manusia yang penting. Dengan melakukan hal itu, ia melampaui model yang ada dan melaporkan model proses umum dari pembangunan institusi yang berakar pada pekerjaan empiris. Model baru memiliki implikasi untuk perubahan di tingkat organisasi (sistem mikro) dan sosial (sistem makro).

Sementara itu dalam penelitian ini lebih mengacu pada pendapat Milton J. Esman (1972) yang melihat pengembangan model pembangunan institusi sebagai "perubahan sosial terencana" yang melibatkan "perencanaan, penataan, dan bimbingan organisasi baru atau yang dibentuk kembali". Perubahanperubahan ini melibatkan nilai-nilai sosial, penciptaan pola aksi baru, dan pengenalan teknologi baru. Oleh karena itu, kesuksesan berarti penerimaan sosial, yang dipandang sebagai rooting lembagalembaga baru di lingkungan fisik dan sosial. Lembaga itu sendiri melibatkan sejumlah variabel: kepemimpinan (leadership), kebijakan (doctrine), kegiatan layanan (programme), sumber daya (resources), dan struktur internal (internal structure), yang semuanya ditanamkan dalam lingkungan baru mereka dengan "hubungan" dari berbagai macam, yaitu, struktur dan proses untuk 
NAKHODA: JURNAL ILMU PEMERINTAHAN

Edisi Januari - Juni Tahun 2020 Volume: 19 Nomor: 1

ISSN : 1829-5827 | E-ISSN : 2656-5277

DOI : https://doi.org/10.35967/jipn

https://nakhoda.ejournal.unri.ac.id/index.php/JIPN mengoperasikan dan memelihara lembaga baru. Ini dibagi menjadi hubungan yang memungkinkan, fungsional, normatif, dan tersebar, yang semuanya didefinisikan dan didiskusikan oleh Esman, serta oleh banyak kontributor lainnya (Donald\&Klein, 1974).

\section{a) Leadership atau Kepemimpinan.}

Kepemimpinan dapat di artikan proses mempengaruhi dan mengarahkan para pegawai dalam melakukan pekerjaan yang telah ditugaskan kepada pegawainya (Mintorogo, 1997:2)[11]. Pemimpin dalam sebuah lembaga mengacu pada "sekelompok personil yang secara aktif terlibat dalam perumusan kebijakan dan program lembaga, yang mengarahkan operasi lembaga dan hubungan lembaga dengan lingkungannya." Kepemimpinan merupakan unsur paling penting dalam pengembangan kelembagaan karena proses perubahan yang secara sengaja dilakukan akan memerlukan pengelolaan yang intensif, memerlukan keterampilan dan keahlian khusus, dan komitmen penuh dari internal lembaga.

Selanjutnya Kartini Kartono (2006:

2)[12] menjelaskan bahwa kepemimpinan merupakan cabang dari kelompok ilmu administrasi, khususnya ilmu administrasi negara. Dalam kepemimpinan itu terdapat hubungan antara manusia yaitu, hubungan mempengaruhi 12 dari pemimpin dan hubungan kepatuhan-ketaatan para pengikut karena dipengaruhi oleh kewibawaan pemimpin. Para pengikut terkena pengaruh kekuatan dari pemimpinnya, dan bangkitlah secara spontan rasa ketaatan pada pemimpin.
Kepemimpinan merupakan proses kelompok, di mana berbagai peran seperti pengambilan keputusan dan pengendalian operasional lembaga didistribusikan dalam berbagai pola dalam kelompok kepemimpinan tersebut. Kelompok kepemimpinan harus diartikan selain terdiri dari para pemegang posisi kepemimpinan yang ditunjuk secara struktural juga personil lain yang walaupun tidak memiliki jabatan struktural namun mampu mempunyai pengaruh penting dalam lembaga.

Kepemimpinan adalah proses mempengaruhi dalam menentukan tujuan organisasi, memotivasi perilaku pengikut untuk mencapai tujuan, mempengaruhi untuk memperbaiki kelompok dan budayanya. Seorang pemimpin diharapkan memiliki kemampuan mengarahkan dan memimpin perusahaan atau organisasi untuk maju dalam meraih tujuan kolektif yang diimpikan bersama. Kepemimpinan dipahami dalam pengertian sebagai kekuatan untuk menggerakan dan mempengaruhi orang dan sebagai alat, sarana atau proses untuk membujuk orang agar bersedia melakukan sesuatu dengan ikhlas. Hal ini tidak mungkin diwujudkan pemimpin tanpa adanya interaksi sosial yang baik dengan para pengikutnya. Sehingga, mereka akan bekerja sama layaknya sebuah tim yang solid guna mewujudkan impian bersama. Seorang pemimpin atau manajer adalah bagian dari perusahaan atau organisasi dan tidak bisa dipisahkan dari mereka. Oleh karena itu kepemimpinan pada hakekatnya adalah: 
NAKHODA: JURNAL ILMU PEMERINTAHAN

Edisi Januari - Juni Tahun 2020 Volume: 19 Nomor: 1

ISSN : 1829-5827 | E-ISSN : 2656-5277

DOI : https://doi.org/10.35967/jipn

https://nakhoda.ejournal.unri.ac.id/index.php/JIPN a. Proses mempengaruhi atau memberi contoh oleh pemimpin kepada pengikutnya dalam upaya mencapai tujuan organisasi.

b. Seni mempengaruhi dan mengarahkan orang dengan cara kepatuhan, kepercayaan, kehormatan dan kerja sama yang bersemangat dalam mencapai tujuan bersama.

c. Kemampuan untuk mempengaruhi dan mengarahkan tindakan seseorang atau kelompok untuk mencapai tujuan yang diharapkan.

d. Kemampuan untuk mempengaruhi suatu kelompok untuk mencapai tujuan.

Praktek kepemimpinan berkaitan dengan mempengaruhi tingkah laku dan perasaan orang lain baik secara individual maupun kelompok dalam arahan tertentu, sehingga melalui kepemimpinan merujuk pada proses untuk membantu mengarahkan dan memobilisasi orang atau ide-idenya (Veitzhal, 2003:2-4)[13].

\section{b) Doctrine atau Kebijakan.}

Komponen ini didefinisikan sebagai pernyataan nilai-nilai, tujuan dan pendekatan yang mendasari tindakan lembaga." Kebijakan lembaga adalah irisan antara serangkaian kebijakan di dalam organisasi itu sendiri dan dalam lingkungan lembaga yang bersifat eksternal yang menggambarkan visi, harapan dan tujuan lembaga. Mengutip pendapat Apeldorn, doktrin hanya membantu dalam pembentukan norma, doktrin itu harus dipindahkan lebih dahulu ke dalam norma yang langsung misalnya putusan hakim atau peraturan perundangundangan sehingga doktrin itu menjadi sumber tidak langsung dalam penerapan hukum. Menurutnya ajaran berbeda dengan teori. Suatu ajaran membahas pada satu hal tertentu atau satu pasal tertentu yang lebih kecil dan belum berlaku secara umum. Ketika ajaran tersebut diobjektifkan dan berlaku secara umum maka akan berubah menjadi teori. Apa yang dikemukakan oleh B. Arief Sidarta tentang pemaknaan doktrin, hampir sama seperti yang dikemukan oleh Agell (2002). Dia mengatakan bahwa doktrin dalam ilmu hukum diartikan sebagai "analytical study of law atau "doctrinal study of law" yang bersifat science. "Legal doctrine" adakalanya disebut juga dengan "legal dogmatics". Kedua istilah ini lazim ditemukan dalam civil law sementara itu di dalam anglo-american istilah legal doctrine maupun legal dogmatic tidak begitu dikenal. Jufrina Rizal (2013) memberikan pemaknaan atas kedua terminologi tersebut sebagai berikut : "Istilah ajaran di Indonesia penggunaannya bermacam-macam, ada ajaran hukum alam, ajaran positivisme, ajaran hukum murni, ajaran hukum progresif, padahal itu semua adalah teori juga. "Ajaran" digunakan untuk menjelaskan isi dari teori tersebut. Karena itu, Kelsen juga menyebutkan "reine rechlehre" yang diterjemahkan ajaran hukum murni. Lehre (Jerman), leer (Belanda) diterjemahkan sebagai ajaran. Dalam bahasa asing terminologi ini akan lebih jelas, misalnya 
algemene rechlehre/general jurisprudence. Perancis sendiri memakai istilah theorie general du Droit, yang diterjemahkan ke dalam Bahasa Indonesia menjadi "ajaran hukum umum". Rechtsleer diterjemahkan sebagai ajaran hukum, Wetenschapsleer diterjemahkan ajaran ilmu dari hukum. Ditemukan juga istilah "ajaran hukum doktrinal". Yang membuat semakin bingung, semua hal itu disebut dengan istilah recht maupun wet (Belanda), atau droit dan lois (Prancis). Di Perancis ada Sociologie $d u$ Droit dan Sociologie Juridique, yang diartikan sebagai Sosiologi Hukum (Sofian, 2016)[14]

\section{c) Programe atau Kegiatan/Layanan.}

Merupakan aktivitas yang berhubungan dengan kinerja masingmasing fungsi lembaga dan merupakan hasil atau output dari lembaga. Program merupakan terjemahan dari kebijakan ke dalam tindakan konkret berdasarkan alokasi sumber daya lembaga dalam hubungannya dengan lingkungan eksternal lembaga. Sementara menurut Friedrich dalam Agustino (2008:7)[15] kebijakan adalah serangkaian tindakan atau kegiatan yang diusulkan oleh seseorang, kelompok, atau pemerintah dalam suatu lingkungan tertentu dimana terdapat hambatanhambatan (kesulitan-kesulitan) dan kemungkinan-kemungkinan (kesempatankesempatan) dimana kebijakan tersebut diusulkan agar berguna dalam mengatasinya untuk mencapai tujuan yang dimaksud.
Implementasi kebijakan merupakan tahap yang krusial dalam proses kebijakan publik. Suatu program kebijakan harus diimplementasikan agar mempunyai dampak atau dapat mencapai tujuan yang diinginkan. Studi implementasi merupakan suatu kajian mengenai studi kebijakan yang mengarah pada proses pelaksanaan dari suatu kebijakan. Menurut Udoji dalam Agustino (2008:140) mengatakan bahwapelaksanaan kebijakan adalah sesuatu yang penting bahkan mungkin jauh lebih penting dari pada pembuatan kebijakan. Kebijakan-kebijakan hanya akan sekedar berupa impian atau rencana bagus yang tersimpan rapi dalam arsip kalau tidak diimplementasikan.

\section{d) Resources atau Sumber Daya.}

Merupakan sumber daya keuangan, SDM, teknologi dan informasi yang menjadi masukan atau input bagi lembaga. Cukup jelas bahwa masalah mobilisasi sumber daya dan memastikan ketersediaan sumber daya secara stabil akan mempengaruhi setiap aspek kegiatan lembaga dan sangat tergantung pada kehandalan aspek kepemimpinan lembaga. Sumber daya manusia adalah orang-orang yang ada dalam organisasi yang memberikan sumbangan pemikiran dan melakukan berbagai jenis pekerjaan dalam mencapai tujuan organisasi. Sumbangan yang dimaksud adalah pemikiran dan pekerjaan yang mereka lakukan di berbagai kegiatan dalam perusahaan. Dalam pengertian sumber daya manusia, yang diliput bukanlah terbatas kepada tenaga ahli, tenaga pendidikan ataupun tenaga yang berpengalaman saja tetapi 
NAKHODA: JURNAL ILMU PEMERINTAHAN

Edisi Januari - Juni Tahun 2020 Volume: 19 Nomor: 1

ISSN : 1829-5827 | E-ISSN : 2656-5277

DOI : https://doi.org/10.35967/jipn

https://nakhoda.ejournal.unri.ac.id/index.php/JIPN semua tenaga kerja yang digunakan perusahaan untuk mewujudkan tujuantujuannya (Sukirno, 2006:172)[16].

Kata "Sumber Daya" menurut Poerwadarminta dalam (Martoyo, 1992:2)[17] menjelaskan bahwa dari sudut pandang etimologis kata "sumber" diberi arti "asal" sedangkan kata "daya" berarti "kekuatan" atau "kemampuan". Dengan demikian sumber daya artinya "kemampuan", atau "asal kekuatan". Pendapat lain mengatakan bahwa Sumber Daya diartikan sebagai alat untuk mencapai tujuan atau kemampuan memperoleh keuntungan dari kesempatankesempatan tertentu, atau meloloskan diri dari kesukaran sehingga perkataan sumber daya tidak menunjukkan suatu benda, tetapi dapat berperan dalam suatu proses atau operasi yakni suatu fungsi operasional untuk mencapai tujuan tertentu seperti memenuhi kepuasan. Dengan kata lain sumber daya manusia merupakan suatu abstraksi yang mencerminkan aspirasi manusia dan berhubungan dengan suatu fungsi atau operasi (Martoyo, 1992: 2).

Penjelasan mengenai manusia sebagai sumber daya menunjukkan bahwa manusia adalah makhluk yang unik dan komplek, yang dalam bekerja di lingkungan sebuah perusahaan harus diperlakukan dengan kualitas kehidupan kerja yang baik agar memungkinkannya bekerja secara efektif, efisien, produktif dan berkualitas. Di antaranya dalam bentuk memberikan kesempatan untuk berpartisipasi mengembangkan karirnya, dierlakukan adil dalam menyelesaikan konflik yang dihadapinya, disupervisi secara jujur dan obyektif, memperoleh upah yang layak dan lain lain (Mangkunegara, 2001: 56)[18]

\section{e) Internal Structure atau Struktur Organisasi.}

Struktur didefinisikan sebagai struktur dan proses yang disusun untuk penyelenggaraan operasi lembaga. Struktur akan terdiri dari soal distribusi peran dalam organisasi, pola otoritas, sistem komunikasi, tugas dan tanggung jawab masing-masing personil dan kapasitas yang dibutuhkan untuk melaksanakan hal tersebut. Menurut Barnard dalam buku Wursanto (2005:53)[19] mendefinisikan organisasi adalah suatu sistem usaha bersama antara dua orang atau lebih, sesuatu yang tidak berwujud dan tidak bersifat pribadi, yang sebagian besar mengenai hubungan-hubungan kemanusiaan. Sementara itu menurut Atmosudirdjo dalam buku Wursanto (2005:53) mendefinisikan organisasi itu sebagai struktur tata pembagian kerja dan struktur tata hubungan kerja antara sekelompok orang-orang pemegang posisi yang bekerjasama secara tertentu untuk bersama-sama mencapai tujuan yang tertentu.

Penyusunan struktur organisasi merupakan langkah awal dalam memulai pelaksanaan kegiatan organisasi, dengan kata lain penyusunan struktur organisasi adalah langkah terencana dalam suatu perusahaan untuk melaksanakan fungsi perencanaan, pengorganisasian, pengarahan, dan pengawasan. Menurut Siswanto (2005:85)[20] struktur organisasi menspesifikasikan pembagian kerja dan 
NAKHODA: JURNAL ILMU PEMERINTAHAN

Edisi Januari - Juni Tahun 2020 Volume: 19 Nomor: 1

ISSN : 1829-5827 | E-ISSN : 2656-5277

DOI : https://doi.org/10.35967/jipn

https://nakhoda.ejournal.unri.ac.id/index.php/JIPN menunjukkan bagaimana fungsi atau aktivitas yang beraneka ragam yang dihubungkan sampai batas tertentu, juga menunjukkan tingkat spesialisasi aktivitas kerja. Selanjutnya menurut Hasibuan (2010:128)[21] struktur organisasi adalah suatu kondisi yang menggambarkan tipe organisasi, pendepartemenan organisasi kedudukan, dan jenis wewenang pejabat, bidang dan hubungan pekerjaan, garis perintah dan tanggung jawab, rentang kendali dan sistem pimpinan organisasi.

\section{METODE PENELITIAN}

Adapun metode yang digunakan dalam penelitian ini yakni menggunakan pendekatan kualitatif. Penelitian kualitatif dieksplorasi dan diperdalam dari fenomena sosial dan lingkungan sosial yang terdiri atas pelaku, kejadian, tempat, dan waktu. Menurut John W. Creswell (2016:4)[22] bahwa penelitian kualitatif merupakan metode-metode untuk mengeksplorasi dan memahami makna yang oleh sejumlah individu atau sekelompok orang dianggap berasal dari masalah sosial atau kemanusiaan. Penelitian kualitatif ini di desain dengan prosedur tertentu, dengan mengumpulkan data dari informan yang terkait dengan konteks penelitian dan kemudian menginterprestasikan data tersebut menurut sumber dan situasi yang ada. Pemilihan metode kualitatif, didasarkan pada alasan untuk mengungkapkan persoalan penelitian yang berkaitan dengan pembangunan kelembagaan dalam mengatasi persoalan pertambangan emas tanpa izin di Kabupaten Kuantan Singingi Provinsi Riau. Adapun yang menjadi informan dalam penelitian ini yakni terdiri dari pegawai Dinas ESDM Provinsi Riau, anggota DPRD Riau, Asisten III Setda Kabupaten Kuantan Singingi, Pegawai Polres Kabupaten Kuantan Singingi, Pegawai Dinas Lingkungan Hidup Kabupaten Kuantan Singingi, Kepala Desa dan masyarakat. Teknik penentuan informan dalam penelitian dilakukan dengan cara purposive yakni untuk menggali informasi secara mendalam sesuai dengan karakteristik penelitian pada situasi dan kondisi tertentu. Sementara itu dalam penelitian ini teknik pengumpulan data dilakukan dengan cara wawancara, observasi dan dokumentasi. Wawancara dilakukan kepada sejumlah informan yang berkompeten dan mengetahui terkait dengan kegiatan PETI yang sekaligus melakukan pengamatan terhadap perilaku dan aktivitas individu tersebut di lokasi penelitian. Sedangkan dokumen yang diperoleh dalam penelitian berasal dari berita media cetak dan elektronik, dokumen resmi, makalah dan hasil rapat. Teknik analisis data yang digunakan yakni berdasarkan penyajian dengan menerapkan pendekatan narasi/laporan kualitatif dalam menyampaikan hasil analisis terkait dengan persoalan PETI.

\section{HASIL DAN PEMBAHASAN}

\section{Leadership (Kepemimpinan).}

Pemimpin dalam sebuah lembaga mengacu pada "sekelompok personil yang secara aktif terlibat dalam perumusan kebijakan dan program lembaga, yang mengarahkan operasi lembaga dan hubungan lembaga dengan lingkungannya." Kepemimpinan merupakan unsur paling penting dalam pengembangan kelembagaan karena proses perubahan yang secara sengaja dilakukan 
NAKHODA: JURNAL ILMU PEMERINTAHAN

Edisi Januari - Juni Tahun 2020 Volume: 19 Nomor: 1

ISSN : 1829-5827 | E-ISSN : 2656-5277

DOI : https://doi.org/10.35967/jipn

https://nakhoda.ejournal.unri.ac.id/index.php/JIPN akan memerlukan pengelolaan yang intensif, memerlukan keterampilan dan keahlian khusus, dan komitmen penuh dari internal lembaga. Kepemimpinan merupakan proses kelompok, di mana berbagai peran seperti pengambilan keputusan dan pengendalian operasional lembaga didistribusikan dalam berbagai pola dalam kelompok kepemimpinan tersebut. Kelompok kepemimpinan harus diartikan selain terdiri dari para pemegang posisi kepemimpinan yang ditunjuk secara struktural juga personil lain yang walaupun tidak memiliki jabatan struktural namun mampu mempunyai pengaruh penting dalam lembaga (Esman, 1972).

Selanjutnya terkait dengan persoalan pertambangan emas tanpa izin di Kabupaten Kuantan Singingi, Gubernur sebagai pemegang kewenangan pertambangan berdasarkan UndangUndang Nomor 23 Tahun 2014 tentang Pemerintahan Daerah, diberikan kekuasaan untuk menerbitkan izin usaha pertambangan kepada pelaku usaha dengan prasyarat yang harus dipenuhi oleh calon pelaku usaha. Sebagai konsekuensi dari efisiensi/penyederhanaan kewenangan dalam hal pertambangan, maka pemerintah daerah provinsi memiliki kewenangan sebagai berikut:

1. Penetapan wilayah izin usaha pertambangan mineral bukan logam dan batuan dalam 1 daerah provinsi dan wilayah laut sampai dengan 12 mil

2. Penerbitan izin usaha pertambangan mineral logam dan batubara dalam rangka penanaman modal dalam negeri pada wilayah izin usaha pertambangan daerah yang berada dalam 1 daerah provinsi termasuk wilayah laut sampai dengan 12 mil laut.

3. Penerbitan izin usaha pertambangan mineral bukan logam dan batuan dalam rangka penanaman modal dalam negeri pada wilayah izin usaha pertambangan yang berada dalam 1 daerah provinsi termasuk wilayah laut sampai dengan 12 mil laut.

4. Penerbitan izin pertambangan rakyat untuk komoditas mineral logam, batubara, mineral bukan logam dan batuan dalam wilayah pertambangan rakyat.

5. Penerbitan izin usaha pertambangan operasi produksi khusus untuk pengolahan dan pemurnian dalam rangka penanaman modal dalam negeri yang komoditas tambangnya berasal dari 1 daerah provinsi yang sama.

6. Penerbitan izin usaha jasa pertambangan dan surat keterangan terdaftar dalam rangka penanaman modal dalam negeri yang kegiatan usahanya dalam 1 daerah provinsi

7. Penetapan harga patokan mineral bukan logam dan batuan.

Peran kepemimpinan dalam penanganan pertambangan emas tanpa izin (PETI) di Kabupaten Kuantan Singingi sangat diperlukan agar dapat megelola hasil sumber daya alam berupa emas tersebut untuk kepentingan masyarakat banyak. Peran pemerintah daerah provinsi yakni gubernur maupun pemerintah kabupaten melalui bupati sangat berpengaruh terhadap eksistensi potensi emas yang ada di Provinsi Riau khususnya di Kabupaten Kuantan Singingi. Berdasarkan hasil penelitian didapati bahwa belum maksimalnya peran yang dilakukan oleh para pemimpin formal 
NAKHODA: JURNAL ILMU PEMERINTAHAN

Edisi Januari - Juni Tahun 2020 Volume: 19 Nomor: 1

ISSN : 1829-5827 | E-ISSN : 2656-5277

DOI : https://doi.org/10.35967/jipn

https://nakhoda.ejournal.unri.ac.id/index.php/JIPN seperti gubernur dan pemerintah provinsi melalui dinas ESDM dan pemerintah setempat sebagai pemilik lokasi penambangan untuk merespon solusi atas kegiatan ilegal tersebut. Hal ini terlihat dari masih terdapatnya kasus penambangan ilegal yang dilakukan oleh individu dan masyarakat pelaku PETI sejak 5 tahun terakhir (dapat dilihat pada tabel 1 tentang data jumlah kasus PETI di Kabupaten Kuantan Singingi). Selain itu, lemahnya pengaturan yang menyangkut dengan pertambangan emas di Riau, yang menuntut peran kepemimpinan kepala daerah provinsi dan DPRD sebagai pemegang kewenangan pertambangan dan pembuat kebijakan dalam bentuk peraturan daerah tentang pertambangan rakyat. Sementara itu, hal yang lebih ironis lagi, munculnya keterlibatan oknum pemerintah asebagai pemodal dalam kegiatan penambangan emas ilegal tersebut. Oleh karenanya, peran kepemimpinan kepala daerah baik provinsi maupun kabupaten, desa dan DPRD merupakan elemen yang penting dalam menentukan arah kebijakan tentang pertambangan emas di Riau khususnya di Kabupaten Kuantan Singingi. Kepemimpinan formal yang terdiri dari gubernur bersama bupati dan DPRD perlu melakukan diskusi dengan melibatkan unsur yang terkait dan Forkompinda untuk membahas tentang pengelolaan pertambangan emas di Kabupaten Kuantan Singingi. Produk kebijakan layaknya peraturan daerah tentang pertambangan sejatinya diperlukan guna untuk mengatur legalitas kegiatan pertambangan di Kabupaten Kuantan Singingi. Keberadaan lembaga kepemimpinan (leadership) formal dalam suatu komunitas memainkan peran signifikan dan dalam kondisi tertentu mampu menghentikan proses dan progres perubahan sosial di wilayahnya. Fungsi utama lembaga kepemimpinan formal adalah sebagai mobilisator anggota lembaga organisasi, sebagai pusat dan penyalur informasi, dan berbagai fungsi sosial lainnya.

Sementara itu peran lembaga kepemimpinan non formal juga memiliki potensi untuk dimanfaatkan secara positif dalam berbagai upaya untuk mengatasi persoalan pertambangan emas yang terjadi di Kabupaten Kuantan Singingi. Hal ini diperkuat dengan hasil penelitian yang dilakukan oleh Kuntowijoyo (1980) yang menunjukkan kuatnya posisi dan peran lembaga kepemimpinan lokal pada sistem sosial etnis Madura, dimana kedua peran kepemimpinan lokal tersebut terdiri dari tokoh negara dan tokoh agama (Suradisastra, 2017:281-315)[23].

Begitupun hal nya dengan persoalan PETI di Kabupaten Kuantan Singingi. Peran dari kepemimpinan non formal diperlukan untuk mempengaruhi masyarakat agar berpartisipasi dalam keterlibatannya menjadi bagian dari perumusan kebijakan terkait dengan penanganan PETI di Kabupaten Kuantan Singingi. Peran serta dari ninik mamak, tokoh adat, tokoh agama dan pemuda tentunya memberikan pengaruh yang begitu besar terhadap aktivitas masyarakat khsususnya yang menyangkut dengan pertambangan emas. Betapa tidak, kebiasaan dan tradisi "mendulang" yang telah dilakukan turun temurun oleh masyarakat mulai memudar sejak belakangan ini seiring berkembangnya tren menambang dengan menggunakan alat modern yang relatif lebih cepat dan mendapatkan hasil yang banyak. Melemahnya peran dari kepemimpinan 
non formal belakangan ini disebabkan oleh adanya imbalan berupa materi yang diperoleh dari sistem bagi hasil yang dilakukan oleh para pelaku tambang dengan unsur pemimpin non formal seperti tokoh pemuda, dan tokoh adat tersebut sehingga perilaku mereka lebih cenderung permisif dan pasif terhadap aktivitas tambang yang tidak mengantongi izin tersebut.

Disamping melemahnya peran kepemimpinan non formal, sejumlah informan juga menjelaskan bahwa kehadiran para pekerja tambang yang sengaja didatangkan dari luar Riau dan Kuantan Singingi membuat kesenjangan dengan masyarakat lokal. Hal ini dikarenakan mereka yang bekerja sebagai penambang mendapatkan pendapatan lebih dibandingkan dengan masyarakat tempatan yang sebagian besar bekerja sebagai petani karet dan sawit. Meski demikian lanjut Iwan masyarakat setempat tidak dapat berbuat banyak dikarenakan yang menjadi pemodalnya adalah masyarakat lokal juga yang sengaja membeli atau menyewa lahan untuk dijadikan sebagai lokasi tambang ilegal tersebut.

Berdasarkan fakta empirik jika dikaitkan dengan teori, jelas bahwa peran kepemimpinan sangat berpengaruh terhadap upaya menyelesaikan suatu persoalan. Hal ini sesuai dengan pendapat Bergsten (dalam Vidhya, 2009), dalam sebuah artikel yang membahas tentang apa yang melemahkan beberapa lembaga internasional besar seperti OPEC dan GATT, dan apa yang diperlukan untuk mereformasi mereka, menekankan perlunya kepemimpinan kolektif di seluruh negara, karena tidak ada satu negara pun yang dapat mengklaim dominasi atas yang lain dalam konteks saat ini. Dia juga menyoroti perlunya kolaborasi informal sebagai rute menuju koordinasi yang efektif.

\section{Doctrine (Kebijakan)}

Kebijakan lembaga adalah irisan antara serangkaian kebijakan di dalam organisasi itu sendiri dan dalam lingkungan lembaga yang bersifat eksternal yang menggambarkan visi, harapan dan tujuan lembaga. Menurut Thomas R. Dye kebijakan dapat dipandang sebagai sebuah sistem. Oleh karenanya jika kebijakan dipandang sebagai sebuah sistem, maka kebijakan memiliki elemen-elemen pembentuknya. Adapun elemen tersebut dapat dilihat pada gambar berikut:

Gambar 2

Tiga Elemen Sistem Kebijakan

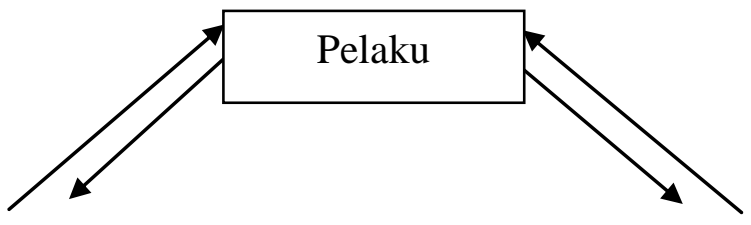


NAKHODA:

JURNAL
NAKHODA: JURNAL ILMU PEMERINTAHAN

Edisi Januari - Juni Tahun 2020 Volume: 19 Nomor: 1

ISSN : 1829-5827 | E-ISSN : 2656-5277

DOI : https://doi.org/10.35967/jipn

https://nakhoda.ejournal.unri.ac.id/index.php/JIPN

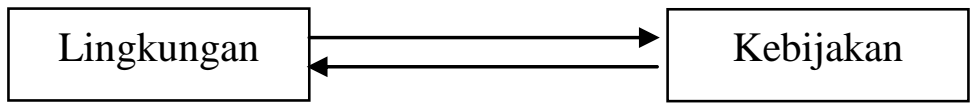

Sumber: Thomas R. Dye (dalam Dunn, 2000:110)

Menurut Thomas R. Dye (dalam Dunn, 2000:110)[24] terdapat tiga elemen kebijakan yang membentuk sistem kebijakan. Dye menggambarkan ketiga elemen kebijakan tersebut sebagai kebijakan publik/public policy, pelaku kebijakan/policy stakeholders, dan lingkungan kebijakan/policy environment. Lebih lanjut Thomas Mengatakan bahwa Pelaku kebijakan yakni orang yang mempunyai wewenang yang sah untuk ikut serta dalam formulasi hingga penetapan kebijakan publik. Pelaku kebijakan memang dapat mempunyai peran penting dalam kebijakan, namun mereka juga dapat pula dipengaruhi oleh keputusan pemerintah. Lingkungan kebijakan juga mempengaruhi dan dipengaruhi oleh pembuat kebijakan dan kebijakan publik itu sendiri.

Berkaitan dengan perkembangan aktivitas pertambangan emas tanpa izin (PETI) di Kabupaten Kuantan Singingi, ditemukan bahwa belum adanya kebijakan skala daerah seperti peraturan daerah yang mengatur tentang pertambangan rakyat sehingga hal ini yang menyebabkan lemahnya dasar hukum yang dalam mengatasi persoalan PETI. Keterlibatan oknum pemerintah sebagai aktor tersembunyi yang memberikan bantuan modal kepada pelaku tambang dengan sistem bagi hasil, menyebabkan aktifnya perkembangan PETI di hampir sebagian besar wilayah di Kabupaten Kuantan Singingi. Kebijakan sejatinya merupakan dasar hukum bagi penyelenggara pemerintahan dalam melaksanakan tugas dan kewenangannya. Jika hal ini lemah, maka akan berdampak terhadap proses keberlangsungan pemerintahan. Oleh karena itu, persoalan ini menuntut keterlibatan semua elemen baik pemerintah maupun lembaga non pemerintah untuk merumuskan kebijakan yang mengatur tentang pertambangan. Peraturan daerah tentang pertambangan merupakan salah satu solusi bagi terselenggaranya pengelolaan potensi emas di Provinsi Riau khususnya di Kabupaten Kuantan Singingi. Pemberian izin usaha pertambangan (IUP) kepada pelaku usaha tentunya tidak terlepas dari legalitas wilayah yang akan dilakukan eksplorasi oleh masyarakat sebagai wilayah resmi pertambangan rakyat. Persoalan lingkungan, limbah industri dan juga abrasi sungai akibat aktivitas PETI akan terjawab sekiranya lahir peraturan daerah tentang pengelolaan tambang emas di Riau sebagai perwujudan dari cita-cita pemerintah dalam mensejahterakan masyarakat. lemahnya aturan hukum merupakan salah satu faktor penyebab, sehingga hal ini terkesan memberi keleluasaan dan tidak menimbulkan efek jera kepada pelaku penambangan. Memang secara umum masyarakat Kabupaten Kuantan Singingi mengharapkan bagaimana kebijakan pemerintah dapat memberikan solusi untuk mengatasi persoalan PETI dan juga dampak yang ditimbulkan akibat aktivitas tersebut. Namun disisi lain pemerintah juga belum menyiapkan produk aturan yang dapat menaungi kegiatan 
NAKHODA: JURNAL ILMU PEMERINTAHAN

Edisi Januari - Juni Tahun 2020 Volume: 19 Nomor: 1

ISSN : 1829-5827 | E-ISSN : 2656-5277

DOI : https://doi.org/10.35967/jipn

https://nakhoda.ejournal.unri.ac.id/index.php/JIPN pertambangan masyarakat di Kabupaten Kuantan Singingi. Dinas Energi dan Sumber Daya Mineral Riau pernah mengupayakan untuk mengajukan draft rancangan peraturan daerah kepada DPRD Riau, namun hal tersebut tidak menjadi hal prioritas oleh lembaga tersebut sewaktu dalam pembahasan karena juga menyangkut anggaran. Selain itu peran bupati beserta jajaran harus benar-benar menjadikan persoalan ini sebagai agenda untuk dibahas bersama dengan pemerintah provinsi dengan melibatkan unsur-unsur terkait.

Keterlibatan multi aktor dalam menyelesaikan persoalan PETI di Kabupaten Kuantan Singingi merupakan kondisi yang tidak dapat dipisahkan dari pembahasan ini. Pemerintah provinsi, DPRD yang melibatkan pemerintah kabupaten sebagai lembaga formal diberikan kekuasaan untuk melahirkan peraturan daerah yang mengatur tentang kegiatan pertambangan emas di Riau. sementara itu, kehadiran lembaga non formal seperti LSM, kelompok kepentingan dan warga negara sebagai partisipan juga turut memberikan pengaruh terhadap lahirnya kebijakan yang mengatasnamakan kepentingan masyarakat umum. Sebagaimana pendapat yang dinyatakan oleh Thomas R. Dye diatas, bahwa untuk melahirkan sebuah kebijakan harus melibatkan elemen-elemen penting dalam kebijakan yang meliputi aktor/pelaku kebijakan yang dalam hal ini terdiri dari pejabat pemerintah pembuat kebijakan baik eksekutif maupun legislatif, yang kemudian didukung oleh lingkungan kebijakan dapat berupa aspek ekonomi, sosial dan politik.
Sementara itu, para pembuat kebijakan baik eksekutif (Pemerintah Provinsi Riau) maupun legislatif (DPRD Riau) ataupun kelompok-kelompok yang turut serta dalam proses perumusan kebijakan, agar lebih mengedepankan kepentingan publik dari pada kepentingan individu maupun kelompok. Selain itu, dalam penyusunan agenda kebijakan aktor yang terlibat yakni terdiri dari pemerintah daerah (eksekutif), DPRD (legislatif), partai politik, tokoh masyarakat, tokoh pemuda dan tokoh agama perlu dilibatkan dalam rangka penyelesaian masalah yang terkait dengan kepentingan masyarakat banyak.

\section{Programe atau Kegiatan/Layanan.}

Kegiatan/layanan yang dimaksudkan dalam tulisan ini merupakan aktivitas yang berhubungan dengan kinerja masing-masing fungsi lembaga dan merupakan hasil atau output dari lembaga. Sebagai pemegang kewenangan pertambangan berdasarkan ketentuan Undang-Undang Nomor 23 Tahun 2014 tentang Pemerintahan Daerah, Pemerintah Provinsi Riau melalui Dinas Energi dan Sumber Daya Mineral pernah melakukan upaya dengan mengajukan wilayah tambang di Kabupaten Kuantan Singingi sebagai wilayah pertambangan rakyat. Sementara itu, dalam hal pengawasan terhadap aktivitas pertambangan emas tanpa izin juga dilakukan oleh pihak kepolisian resort Kabupaten Kuantan Singingi dengan melakukan razia terhadap para penambang ilegal. Adapun data penertiban yang dilakukan oleh pihak kepolisian tersebut dapat dilihat pada tabel dibawah ini: 
NAKHODA: JURNAL ILMU PEMERINTAHAN

Edisi Januari - Juni Tahun 2020 Volume: 19 Nomor: 1

ISSN : 1829-5827 | E-ISSN : 2656-5277

DOI : https://doi.org/10.35967/jipn

https://nakhoda.ejournal.unri.ac.id/index.php/JIPN

Tabel 1.

Data Jumlah Kasus Tindak Pidana PETI Polres Kuantan Singingi

\begin{tabular}{|c|c|c|c|}
\hline NO & TAHUN & JUMLAH KASUS & JUMLAH TERSANGKA \\
\hline 1 & 2014 & 12 & 18 \\
\hline 2 & 2015 & 14 & 25 \\
\hline 3 & 2016 & 25 & 60 \\
\hline 4 & 2017 & 45 & 78 \\
\hline 5 & 2018 & 17 & 23 \\
\hline 6 & 2019 & 3 & 7 \\
\hline & JUMLAH & $\mathbf{1 0 4}$ & $\mathbf{1 9 3}$ \\
\hline
\end{tabular}

Sumber: Polres Kuantan Singingi, 2020

Berdasarkan tabel diatas seperti yang diungkapkan Kanit Polres Kuantan Singingi Bapak Syapriadi bahwa jumlah kasus dan tersangka yang terdata merupakan jumlah kasus yang tertangkap tangan sedang melakukan aktivitas PETI sedangkan yang pada saat dilakukan penertiban tidak didapati pelaku dan hanya menyisakan alat bukti tidak dihitung sebagai kasus. Hal ini berarti bahwa jumlah penambang ilegal yang sedang aktif melakukan kegiatan pertambangan ilegal tersebut melebihi jumlah kasus yang berhasil diperoleh oleh pihak kepolisian.

Upaya yang dilakukan oleh Pemerintah provinsi Riau, Pemerintah Kabupaten Kuantan Singingi yang bekerjasama dengan pihak kepolisian belum sepenuhnya dapat menghentikan aktivitas pertambangan ilegal di Kabupaten Kuantan Singingi. Hal ini terlihat dari masih adanya praktek pertambangan emas yang tidak mengantongi izin ini dihampir sebagian besar kecamatan di wilayah Kabupaten Kuantan Singingi. Oleh karena itu, sinergitas dan kerjasama antara pemerintah provinsi, pemerintah kabupaten, DPRD dan pihak kepolisian diperlukan sebagai langkah konkrit dalam upaya menjalankan kinerja lembaga yang diberikan kewenangan melalui peraturan perundangundangan.

\section{Resources atau Sumber Daya.}

Adapun sumber daya yang dimaksudkan dalam tulisan ini yakni dapat berupa sumber daya keuangan, sumber daya manusia, teknologi dan informasi yang menjadi masukan atau input bagi lembaga. Dalam upaya mengatasi permasalahan PETI di Kabupaten Kuantan Singingi pemerintah melakukan pengawasan melalui penindakan terhadap pelaku PETI yang terdiri dari masyarakat selaku individu, kelompok dan pemodal yang meraup keuntungan secara mandiri dan merugikan masyarakat daerah secara keseluruhan. Upaya pengawasan melalui tindakan penertiban yang dilakukan oleh pihak kepolisian resort Kabupaten Kuantan Singingi juga mengalami hambatan terutama terhadap penyedian sumber daya baik keuangan, sumber daya manusia, teknologi maupun terkendala akibat jauhnya jangkauan lokasi pertambangan yang berada diareal hutan dan perkebunan masyarakat. Sejatinya Pengawasan 
NAKHODA: JURNAL ILMU PEMERINTAHAN

Edisi Januari - Juni Tahun 2020 Volume: 19 Nomor: 1

ISSN : 1829-5827 | E-ISSN : 2656-5277

DOI : https://doi.org/10.35967/jipn

https://nakhoda.ejournal.unri.ac.id/index.php/JIPN diperlukan untuk memperkuat bangunan organisasi. Pengawasan terhadap pemerintah daerah pada dasarnya ditujukan untuk memperkuat otonomi daerah. Berkembangnya praktek pertambangan emas yang tidak mengantongi izin di Kabupaten Kuantan Singingi ini mutlak memerlukan pengawasan dari berbagai kalangan. Adanya kerjasama antara pemerintah baik provinsi, kabupaten maupun pemerintah pusat, pihak keamanan, masyarakat dan tokoh masyarakat setempat yang punya kompetensi untuk melakukan pengawasan baik secara refresif maupun preventif.

Berdasarkan hasil penelitian didapati bahwa pengawasan yang dilakukan dalam permasalahan pertambangan emas tanpa izin mengalami beberapa kendala antara lain:

1. Dana atau biaya

Pengawasan yang dilakukan oleh pemerintah dalam hal ini dari pihak kepolisian beserta pemerintah daerah Kabupaten Kuantan Singingi mengalami keterbatasan anggaran untuk melakukan penertiban terhadap kegiatan PETI di sejumlah wilayah di Kabupaten Kuantan Singingi. Sehingga ini yang membuat pemerintah daerah Kabupaten Kuantan Singingi mengalami kesulitan untuk melakukan pengawasan secara maksimal, sedangkan aktivitas pertambangan emas tanpa izin tersebut masih tetap dilakukan.

2. Fasilitas (kendaraan operasional)

Berkaitan dengan kendala yang dialami oleh Pemerintah Daerah Kabupaten Kuantan Singingi bersama dengan pihak kepolisian selanjutnya yakni terbatasnya fasilitas berupa kendaraan operasional untuk melakukan tindakan pengawasan terhadap pertambangan emas tanpa izin ini. Sehingga dengan kendaraan yang ada tidak memungkinkan bagi pemerintah setempat bersama pihak kepolisian untuk melakukan razia ke berbagai lokasi tempat kegiatan pertambangan emas ilegal tersebut dilakukan.

3. Kekeluargaan dan kesulitan ekonomi

Faktor selanjutnya yang membuat pemerintah kesulitan untuk melakukan pengawasan yakni adanya pertimbangan dari aktor setempat yang memiliki pengaruh yang besar terhadap masyarakat seperti Pemangku Adat, Ninik Mamak, Tokoh Pemuda dan Kepala Desa yang melakukan permisifitas terhadap kegiatan tersebut. Dari beberapa responden yang peneliti lakukan wawancara, sebagian besar dari mereka memberikan komentar bahwa kegiatan pertambangan emas tersebut sudah dianggap hal yang biasa karena yang pemilik modal tersebut merupakan masyarakat setempat yang juga mempekerjakan beberapa orang masyarakat setempat dengan latar belakang ekonomi yang lemah

\section{Internal Structure atau Struktur Organisasi.}

Struktur organisasi dalam konteksi ini didefiniskan sebagai struktur dan proses yang disusun untuk penyelenggaraan operasi lembaga. Struktur akan terdiri dari soal distribusi peran dalam organisasi, pola otoritas, sistem komunikasi, tugas dan tanggung jawab masing-masing personil dan kapasitas yang dibutuhkan untuk melaksanakan hal tersebut. Terkait dengan urusan pertambangan berdasarkan UndangUndang Nomor 23 Tahun 2014 tentang Pemerintahan Daerah sesungguhnya menjadi kewenangan pemerintah provinsi melalui Dinas Energi dan Sumber Daya 
NAKHODA: JURNAL ILMU PEMERINTAHAN

Edisi Januari - Juni Tahun 2020 Volume: 19 Nomor: 1

ISSN : 1829-5827 | E-ISSN : 2656-5277

DOI : https://doi.org/10.35967/jipn

https://nakhoda.ejournal.unri.ac.id/index.php/JIPN
Mineral Provinsi Riau. Sebagai tindak lanjut untuk melaksanakan kewenangan tersebut, Dinas ESDM membentuk cabang dinas di wilayah Kabupaten Kuantan Singingi sebagai mediator antara masyarakat dengan pemerintah terkait dengan penyelenggaraan urusan dibidang pertambangan.

Kegiatan pertambangan emas tanpa izin (PETI) di Kabupaten Kuantan Singingi mengalami kendala untuk dilakukan pengelolaan oleh Pemerintah Kabupaten Kuantan Singingi disebabkan oleh dicabutnya kewenangan pertambangan dari pemerintah kabupaten kepada pemerintah provinsi sehingga peran yang dimiliki oleh pemerintah kabupaten sangat lemah dalam hal pertambangan. Hal ini berkaitan dengan lemahnya keterlibatan peran Pemerintah Kabupaten Kuantan Singingi dalam menyusun perencanaan dan penganggaran karena berkaitan dengan regulasi yang mengatur hal tersebut. Oleh karenanya kerjasama dan keterlibatan pemerintah provinsi dengan pemerintah kabupaten sangat diperlukan sebagai perwujudan dari pembagian dan distribusi peran untuk mengatasi persoalan pertambangan emas tanpa izin di Kabupaten Kuantan Singingi Provinsi Riau.

\section{KESIMPULAN}

Berdasarkan hasil penelitian yang dilakukan didapati bahwa untuk mengatasi persoalan PETI di Kabupaten Kuantan Singingi berkaitan erat dengan konsep institution building (pembangunan kelembagaan) yang disampaikan oleh Milton J. Esman (1972). Hal ini dapat diungkapkan melalui: pertama, diperlukan peran kepemimpinan baik formal maupun informal sangat diperlukan dalam mempengaruhi setiap aktivitas masyarakat yang berkaitan dengan penambangan emas tanpa izin di Kabupaten Kuantan Singingi. Kepemimpinan formal dimaksud yakni aktor yang berasal dari dalam pemerintah yang berperan dalam melahirkan kebijakan. Sedangkan peran kepemimpinan informal seperti tokoh adat, ninik mamak dan tokoh agama juga memberikan peranan penting dalam mengatasi persoalan pertambangan emas yang terjadi di hampir sebagian besar wilayah di Kabupaten Kuantan Singingi.

Kedua, keberadaan peraturan daerah tentang pertambangan rakyat merupakan suatu yang dapat dijadikan sebagai payung hukum dalam mengatasi persoalan PETI agar dapat dikelola dengan baik oleh pemerintah daerah melalui Dinas Energi dan Sumber Daya Mineral Provinsi. Ketiga, meskipun ada upaya yang dilakukan oleh pemerintah, baik provinsi, kabupaten yang bekerjasama dengan pihak kepolisian yang salah satunya melalui penertiban, namun tetap mengalami kendala dari sisi sumber daya diantaranya yakni kendala biaya, fasilitas dan jauhnya jarak tempuh lokasi pertambangan dengan pusat kota yang merupakan elemen ke empat dari konsep tersebut. Kelima, diperlukan adanya keterlibatan dari berbagai pihak baik pemerintah, masyarakat dan pihak keamanan dalam mengatasi persolan pertambangan yang tidak memiliki izin tersebut.

Berdasarkan dari penjelasan tersebut diatas didapat kesimpulan bahwa pembangunan kelembagaan merupakan solusi alternatif dalam mengatasi persoalan PETI di Kabupaten Kuantan Singingi. Hal ini terkait dengan elemen yang diperlukan dalam pembangunan kelembagaan sebagaimana yang dikemukakan oleh 
Milton J. Esman (1972) yakni terdiri dari kepemimpinan, kebijakan, sumber daya, kegiatan/layanan dan struktrur organisasi.

\section{DAFTAR PUSTAKA}

A. A. A. P. Mangkunegara, Manajemen Sumber Daya Manusia Perusahaan. 2003.

Amin Subagio, "Pengembangan Kelembagaan Pangan Masyarakat dalam Pemantapan Ketahanan Pangan dan Ekonomi Masyarakat (Studi Kasus Desa Damparan, Kecamatan Dusun Hilir, Kabupaten Barito Selatan, Provinsi Kalimantan Tengah," IPB.

A. Mintorogo, Kepemimpinan dalam Organisasi. Yogyakarta, 1997.

A. Sofian, Makna "Doktrin" dan "Teori" dalam Ilmu Hukum. 2016.

B. Siswanto, Manajemen Tenaga Kerja Indonesia Pendekatan Administratif dan Operasional. Jakarta, 2005.

D. William N, Pengantar Analisis Kebijakan Publik, Kedua. Yogyakarta: Gadjah Mada University, 2000.

dkk Djogo, Kelembagaan dan Kebijakan dalam Pengembangan Agroforestri. Bogor: KRAF.

I. Wursanto, Dasar-dasar ilmu organisasi. Yogyakarta, 2005.

J. W. Creswell, w Creswell, J. (2009). Research design: Qualitative, quantitative, and mixed methods approaches. SAGE Publications, Incorporated. 2014.

K. Kartono, Pemimpin dan Kepemimpinan. Jakarta, 2006.

K. Suradisastra, "Revitalisasi

Kelembagaan untuk Percepatan Pembangunan Sektor Pertanian dalam Otonomi Daerah, " Revital. Kelembagaan untuk Percepatan Pembang. Sekt. Pertan. dalam Oton. Drh. 2017

L. Agustino, Dasar-dasar Kebijakan Publik. Bandung, 2008.

Malayu S.P Hasibuan, Manajemen Sumber Daya Manusia. 2012

M. J. Esman, "The elements of institution building," in Institution building and development, 1972.

Sadono Sukirno, Pengantar Bisnis. Jakarta, 2006.

S. Martoyo, Manajemen Sumber Daya Manusia. Yogyakarta, 1992.

P. A. Donald, G., de Schweinitz Jr, K., \& Klein, Institution Building and Development: From Concepts to Application. 1974.

R. Veithzal, "Kepemimpinan dan perilaku organisasi," Jakarta PT. Raja Graf., 2008 .

\section{Jurnal :}

A. Moore, M., Stewart, S., \& Hudock, "Institution building as a development assistance method.," SIDA, 1995.

M. Vidhya, "Institution Building. A Review of literature," NHRD Netw. J., vol. 1, 2009.

S. Eriksen, "Institution building in Central and Eastern Europe: Foreign influences and domestic responses," Rev. Cent. East Eur. Law, 2007, doi: 10.1163/092598807X195232.

S. R. Ganesh, "Institution Building for Social and Organizational Change: An Appreciation," Organ. Stud., 1980, doi: 10.1177/017084068000100301.

T. Terada, "Directional leadership in 
NAKHODA: JURNAL ILMU PEMERINTAHAN

Edisi Januari - Juni Tahun 2020 Volume: 19 Nomor: 1

ISSN : 1829-5827 | E-ISSN : 2656-5277

DOI : https://doi.org/10.35967/jipn

https://nakhoda.ejournal.unri.ac.id/index.php/JIPN

institutionbuilding: Japan's

approaches to ASEAN in the establishment of PECC and APEC,"

Pacific Rev., 2001, doi:

10.1080/09512740110037352. 